REFLEKSI HUKUM

Jurnal Ilmu Hukum
p-ISSN 2541-4984 | e-ISSN 2541-5417

Volume 2 Nomor 1, Oktober 2017, Halaman 65 - 80

DOI: https://doi.org/10.24246/jrh.2017.v2.i1.p65-80

Open access at: http://ejournal.uksw.edu/refleksihukum Penerbit: Fakultas Hukum Universitas Kristen Satya Wacana

\title{
KERANGKA PENGATURAN PENGELOLAAN CSR TERPADU (Studi Kasus di Kota Jakarta)
}

\author{
Bani Pamungkas \\ Universitas Bakrie \\ Korespondensi: bani.pamungkas@bakrie.ac.id
}

\begin{abstract}
Abstrak
Pemerintah Provinsi DKI Jakarta memiliki tanggung jawab meningkatkan kesejahteraan dan kemakmuran rakyat serta menjaga kelestarian fungsi lingkungan hidup di daerah. Namun tanggung jawab tersebut tidak dapat dilakukan sendiri. Dibutuhkan dukungan dunia usaha dan masyarakat. Untuk memfasilitasi dukungan tersebut ditetapkan Pergub No. 112 tahun 2013 tentang Tanggung Jawab Sosial dan Lingkungan Dunia Usaha. Penelitian ini mengulas tentang evaluasi ketentuan Pergub tersebut beserta usulan perubahannya. Menggunakan metode penelitian kombinasi yang menggabungkan metode penelitian hukum normatif dan empiris, penelitian ini melakukan kajian empiris dengan menggunakan metode Modified Participatory Action Research. Kombinasi analisis yuridis dengan model perancangan peraturan digunakan pada tahapan analisa. Perbaikan tata kelola TSLDU/CSR, dilakukan melalui 4 (empat) aspek yaitu (1) penyediaan Informasi dan Tata Kelola Administrasi TSLDU/CSR menggunakan Sistem Informasi berbasis web; (2) mengintegrasikan Dukungan TSLDU dengan Sistem Perencanaan Pembangunan dan Anggaran Daerah; (3) Perluasan Ruang Lingkup TSLDU/CSR; dan (4) Mengembangkan Skema TSLDU/CSR Kolaboratif.
\end{abstract}

Kata-kata Kunci: Corporate Social Responsibility; Hibah Daerah; Transparansi; Kolaboratif.

\begin{abstract}
The Jakarta Government has responsibility to improve the welfare and prosperity of the people and to preserve the function of the environment. This responsibility can not be done alone. Business and Community support is required. Jakarta Government issued Government Regulation Number 112 of 2013 regarding the Social and Environmental Responsibility of the Business Sector. This paper study was performed to evaluation of Governor Regulation No. 112 of 2013 and its proposed changes. This study uses a combination of research methods that combine legal research methods of normative and empirical. Empirical study was conducted by Modified Participatory Action Research method. At the analytical stage, a
\end{abstract}


combination of juridical analysis with regulatory modeling is used. Efforts to encourage improvement of governance of TSLDU, 4 (four) aspects need to be addressed, namely (1) Provision of Information and Administration of TSLDU Administration using Web-based Information System; (2) integrating TSLDU Support with the Regional Development Planning and Budgeting System; (3) Expansion of TSLDU Scope; and (4) Developing a Collaborative TSLDU Scheme.

\section{Keywords: Corporate Social Responsibility; Local Donation; Transparancy;} Collaborative.

\section{PENDAHULUAN}

Meningkatkan kesejahteraan dan kemakmuran rakyat serta menjaga kelestarian fungsi lingkungan hidup di daerah merupakan tanggung jawab Pemerintah Daerah. Dalam menjalankan tanggung jawab tersebut, Pemerintah Provinsi DKI Jakarta melalui Peraturan Gubernur No. 112 tahun 2013 tentang Tanggung Jawab Sosial dan Lingkungan Dunia Usaha (Pergub 112) membuka ruang dukungan dunia usaha untuk dapat terlibat dalam pelaksanaan tanggung jawab tersebut melalui pelaksanaan Corporate Social Responsibility (CSR).

Hasil evaluasi internal dan pemeriksaan Badan Pemeriksa Keuangan (BPK) tahun 2016 memberikan catatan terhadap pelaksanaan tanggung jawab sosial dan lingkungan dunia usaha (TSLDU) atau CSR di Provinsi DKI Jakarta yang belum berjalan sesuai prosedur dan ketentuan peraturan perundang-undangan.
Penelitian ini mengulas evaluasi terhadap pelaksanaan Pergub 112 dan menyusun usulan perubahan terhadap tata kelola TSLDU. Pembahasan terdiri dari 2 (dua) bagian. Di bagian pertama diuraikan kerangka pengaturan TSLDU berikut implementasi dan evaluasinya. Pada bagian kedua dibahas usulan perubahan terhadap Pergub 112.

Penelitian ini menggunakan metode penelitian kombinasi yang menggabungkan metode penelitian hukum normatif dan empiris. Secara normatif, dilakukan analisa terhadap peraturan perundangundangan mengenai tata kelola CSR. Sedangkan metode empiris digunakan untuk menggambarkan bagaimana hukum normatif itu berlaku atau dilaksanakan di dalam masyarakat ${ }^{1}$ dengan menggunakan instrumen Modified Participatory Action Research². Melalui instrumen tersebut dielaborasi fakta di lapangan, sekaligus menggali masukan dan gagasan para stakeholders melalui Focus Group Discussion(FGD) ${ }^{3}$. Dilakukan 3 (tiga) seri FGD, dengan mengundang

Soerjono Soekanto dan Sri Mamudji, Penelitian Hukum Normatif: Suatu Tinjauan Singkat (PT Raja Grafindo Persada 1993) 13-14.

2 Gatot Dwi Hendro Wibowo, 'Analisis Kebijakan Pengelolaan Hasil Hutan Bukan Kayu (HHBK) Di NTB Dan NTT' (2014) 44 Jurnal Hukum \& Pembangunan 197, 200.

3 Claudia Pahl-Wostl, 'Participative and Stakeholder-Based Policy Design, Evaluation and Modeling Processes' (2002) 3 Integrated Assessment 3, 6. 
para pemangku kebijakan, SKPD/UKPD teknis maupun wilayah, perwakilan BUMD serta pelaku usaha dan kelompok masyarakat yang terlibat dalam pelaksanaan CSR. Pelaksanaan FGD di fasilitasi Biro Kesejahteraan Sosial Setda Pemprov DKI Jakarta.

Pada tahapan analisa, digunakan kombinasi antara metode analisis yuridis dengan model perancangan peraturan (legal drafting method). Metode analisis yuridis mendasarkan pada teori, konsep serta peraturan perundang-undangan. Sedangkan model perancangan peraturan menggunakan instrumen ILTAM (An Institutional Legislative Theory and Methodology) ${ }^{4}$. Dalam ILTAM, perancangan peraturan ditujukan untuk menciptakan perubahan melalui perubahan perilaku dari para pemangku kepentingan yang terlibat dari suatu permasalahan yang hendak dipecahkan ${ }^{5}$. Melalui model tersebut diharapkan dapat tersusun rancangan peraturan hukum yang efektif dan transformatif.

\section{PEMBAHASAN}

\section{TSLDU Kota Jakarta: Kerangka Pengaturan dan Implementasi}

Kerangka Pengaturan

Pengaturan mengenai TSLDU di Kota Jakarta disusun pada masa Gubernur Joko Widodo. Melalui Pergub No.112 Tahun 2013 (Pergub 112), Pemprov DKI Jakarta berupaya men- sinergikan upaya pemerintah daerah dalam meningkatkan kesejahteraan dan kemakmuran rakyat serta menjaga kelestarian fungsi lingkungan hidup di daerah dengan dukungan dari pelaku usaha melalui tanggung jawab sosial dan lingkungan dunia usaha sebagai kegiatan sukarela. Pergub 112 terdiri dari 10 bab, 18 pasal.

Di dalam Pasal 2 dan Pasal 3 diatur mengenai maksud dan tujuan dari pengaturan TSLDU. Keberadaan Pergub ini dimaksudkan untuk mengatur penyelenggaraan TSLDU dalam rangka optimalisasi program pembangunan daerah. Sedangkan tujuan dari pengaturan TSLDU ialah (a) tersedianya pedoman penyelenggaraan TSLDU termasuk data/informasi lingkungan perusahaan beserta pihak yang menjadi pelakunya; (b) terkoordinasinya penyelenggaraan TSLDU sesuai peraturan perundang-undangan; (c) terwujudnya kepastian hukum bagi perusahaan dalam melaksanakan TSLDU secara terpadu dan berdaya guna; (d) meminimalisir dampak negatif dan mengoptimalkan dampak positif keberadaan perusahaan bagi perusahaan, masyarakat dan lingkungan sekitar perusahaan; dan (e) terwujudnya pemerataan pembangunan melalui pelaksanaan tanggung jawab sosial dan lingkungan. Prinsip pelaksanaan TSLDU diatur dalam Pasal 4. Prinsip pertama, TSLDU merupakan kegiatan sukarela, perusahaan memiliki kebebasan mutlak untuk

$4 \quad$ Ann Seidman and Robert B Saidman, 'ILTAM: Drafting Evidence-Based Legislation for Democratic Social Change' (2009) 89 Boston University Law Review 435, 438.

Ann Saidman and Robert B Saidman, 'Instrumentalism 2.0: Legislative Drafting for Democratic Social Change' (2015) 5 Legisprudence 95, 100. 
menentukan bentuk kegiatan, besarnya dana yang akan dialokasikan atau dibelanjakan dan lokasi kegiatan serta cara/ pola kegiatan TSLDU dilaksanakan. Dan prinsip kedua, TSLDU bukan merupakan kewajiban/kompensasi/persyaratan/insentif atas diberikannya pelayanan perizinan terhadap kegiatan atau aktivitas perusahaan.

Terdapat 4 (empat) lingkup TSLDU, yaitu bina sosial dan budaya, bina ekonomi, bina fisik lingkungan dan penanggulangan bencana. Bentuk kegiatan TSLDU meliputi (1) kegiatan langsung kepada masyarakat; dan (2) melalui keikutsertaan dalam program Pemerintah Daerah, baik melalui kegiatan yang berdampak pada adanya penambahan dan/atau penggunaan Barang Milik Daerah maupun berupa kegiatan jasa/non Barang Milik Daerah yang tidak berdampak pada penambahan dan/atau penggunaan Barang Milik Daerah.

Pasal 8 mengatur 4 (empat) pola pelaksanaan TSLDU. Pola pertama melaksanakan secara langsung, mulai dari perencanaan sampai pelaksanaan. Pola kedua mendanai kegiatan sosial yang langsung dilaksanakan oleh masyarakat berdasarkan proposal yang diajukan. Pola ketiga menggunakan jasa pihak ketiga, organisasi/lembaga kemasyarakatan atau perusahaan yang memberikan jasa, untuk merumuskan dan/atau melaksanakan TSLDU, dan pola keempat beberapa perusahaan bekerja sama mengumpulkan dana untuk membiayai suatu program/ kegiatan sosial kemasyarakatan yang dilaksanakan secara langsung atau melalui pihak ketiga.

Pasal 9 Pergub 112 mengamanatkan pembentukan Forum TSLDU. Pembentukan forum ini diinisiasi oleh unsur dunia usaha, masyarakat dan perguruan tinggi yang difasilitasi oleh pemerintah daerah. Susunan organisasi Forum TSLDU terdiri dari: (a) pembina: Gubernur dan Wakil Gubernur; (b) pengawas: SKPD; (c) pelaksana: ketua dijabat oleh unsur pelaku usaha, wakil ketua dan sekretaris serta anggota dijabat oleh unsur pelaku usaha atau masyarakat atau perguruan tinggi. Kepengurusan dan rincian tugas Forum TSLDU ditetapkan dengan Keputusan Gubernur dengan masa periode tugas selama 3 (tiga) tahun dan dapat dipilih kembali untuk satu periode berikutnya. Forum TSLDU berdasarkan Pasal 9 ayat (6) wajib menyusun Anggaran Dasar dan Anggaran Rumah Tangga dan disahkan oleh Gubernur. Terdapat 5 (lima) tugas Forum TSLDU meliputi: pertama menyatukan komitmen antara pemerintah dengan perusahaan untuk menyinergikan pelaksanaan TSLDU sebagai upaya peningkatan kesejahteraan masyarakat dan kualitas lingkungan; kedua merumuskan strategi, program dan kegiatan yang dilakukan oleh perusahaan dalam upaya sinergitas pelaksanaan TSLDU; ketiga melakukan pertemuan secara periodik paling kurang 3 (tiga) bulan sekali; keempat melaporkan kegiatan TSLDU kepada Gubernur secara periodik setiap 3 (tiga) bulan sekali; dan kelima mempublikasikan kegiatan TSLDU secara terbuka dan dapat diak- 
ses oleh masyarakat umum. Dalam hal Forum TSLDU menerima dana dari pelaksanaan TSLDU, maka semua dana tersebut dipertanggungjawabkan dan dilaporkan kepada pemberi dana dan dilakukan audit sesuai dengan ketentuan peraturan perundang-undangan. Tahapan pelaksanaan TSLDU, diatur dalam Pasal 12 ayat (1) berupa perencanaan, pelaksanaan, pelaporan dan monitoring serta evaluasi. Pada tahapan perencanaan, perusahaan menyusun konsep perencanaan kegiatan TSLDU yang jelas, lengkap dan terperinci hingga teknis pelaksanaan kegiatan atau program; membangun pengertian dan komitmen bersama para pihak yang terlibat, salah satunya dengan pola musrenbang yang dituangkan dalam dokumen dan ditandatangani para pihak yang terlibat; memobilisasi dunia usaha, sumber daya manusia dan teknologi serta dana dan kelembagaan; dan mensosialisasi komitmen berikut program yang akan dilaksanakan kepada para pihak yang telibat.

Pelaksanaan kegiatan dilakukan secara mandiri, baik oleh Forum TSLDU atau perusahaan, maupun secara bersama-sama oleh keduanya dengan mendasarkan pada rekomendasi teknis dan pengawasan dari masyarakat dan SKPD terkait. Bila terjadi permasalahan atau hambatan dalam pelaksanaan maka Forum TSLDU mendapat mandat dari Pasal 13 ayat (2), berkoordinasi dengan SKPD dan pihak terkait untuk menyelesaikannya. Dalam hal pembiayaan operasional Forum TSLDU, dibebankan pada dana TSLDU masing-masing perusahaan dan sumber-sumber lain yang sah dan tidak mengikat.

Pelaporan hasil pelaksanaan TSLDU, sesuai Pasal 14 disampaikan kepada Forum TSLDU dengan tembusan kepada SKPD terkait. Laporan memuat realisasi pelaksanaan dan anggaran penyelenggaraan program TSLDU.

Pasal 15 Pergub 112 memandatkan monitoring dan evaluasi (monev) kegiatan TSLDU kepada SKPD terkait. Hasil monev dilaporkan kepada Gubernur melalui Sekretaris Daerah, serta selanjutnya dicatat ke dalam laporan keuangan SKPD.

Pemprov DKI Jakarta memberikan fasilitas kemudahan pelayanan kepada perusahaan yang melaksanakan kegiatan TSLDU, dengan tetap memenuhi kewajiban sesuai aturan. Selain kemudahan, Pemprov DKI Jakarta memberikan penghargaan berupa pemasangan logo/papan nama identitas perusahaan pada lokasi TSLDU sesuai ketentuan dan pemberian sertifikat. Seluruh pembiayaan dimaksud dibebankan kepada APBD.

\section{Implementasi}

Selama tahun 2016, terdapat 3 jenis kegiatan TSLDU yang berjalan ${ }^{6}$. Ketiga kegiatan tersebut meliputi (1) TSLDU dalam bentuk aset, (2) TSLDU dalam bentuk jasa, dan (3) TSLDU dalam bentuk barang.

$6 \quad$ BPK Perwakilan Provinsi DKI Jakarta, 'Laporan Hasil Pemeriksaan Atas Laporan Keuangan Pemerintah Provinsi DKI Jakarta Tahun Anggaran 2016’ (BPK Perwakilan Provinsi DKI Jakarta). 
Dalam jenis yang pertama, terdapat 7 (tujuh) kegiatan berdasarkan Perjanjian Kerjasama (PKS) yang dibuat oleh Pemprov DKI Jakarta dengan perusahaan pelaksana TSLDU. Kegiatan tersebut berupa penyediaan fasilitas ruang publik terpadu ramah anak yang diberikan 5 (lima) perusahaan berskala besar dan 1 (satu) yayasan. Keenam perusahaan tersebut adalah PT Astra Internasional Tbk; PT Indofood Sukses Makmur Tbk; PT Greenwood Sejahtera Tbk \& PT Kencana Graha Optima; PT Bumi Serpong Damai, Tbk; dan PT Gajah Tunggal Tbk dan Yayasan Sekolah Belajar Aktif Indonesia 1996 (Highscope Indonesia). Pelaksanaan TSLDU berbentuk aset ini, berada pada beragam lokasi yang berbeda.

Dalam TSLDU jenis kedua, terdapat 7 (tujuh) kegiatan yang dapat dikelompokkan dalam 3 (tiga) kluster kegiatan. Pertama jasa dukungan terhadap pembangunan infrastruktur; keduajasa dukungan kegiatan; dan ketiga jasa dukungan keahlian.

Jasa dukungan pembangunan infrastruktur, dilakukan di Kawasan Kota Tua dan Jembatan Kota Intan oleh PT ICI Paints Indonesia selama 2 (dua) tahun. Selain itu berupa revitalisasi infrastruktur sosial air mancur Bundaran Hotel Indonesia (HI), yang dilakukan secara kolektif oleh PT Bank Central Asia Tbk, PT Plaza Indonesia Realty Tbk, PT Wisma Nusantara Internatinal, PT Grand Indonesia, PT Indofood Sukses Makmur Tbk, PT Astra Internasional Tbk dan PT

Ibid.
DREI Indonesia. Kegiatan dimaksud berlangsung selama 12 bulan.

Untuk jasa dukungan kegiatan, TSLDU dilakukan melalui kegiatan peningkatan program keahlian gizi balita oleh Yayasan Amway Peduli selama 3 (tiga) tahun. Kegiatan yang lain ialah penyelenggaraan Lomba Lari Jalan Raya Milo Jakarta Internasional 10 k 2016 oleh PT Nestle Indonesia selama 15 hari (15-31 Agustus 2016).

Dalam jasa dukungan keahlian, TSLDU diberikan oleh PT Deloitte Konsultan Indonesia dalam bentuk dukungan staf untuk penajaman awal dokumen KUA-PPAS APBD tahun anggaran 2017. Dukungan ini diberikan dalam 2 (dua) tahap yaitu pada 11-15 Mei 2016 dan 11 Mei s.d 1 Juli 2016.

Untuk TSLDU berbentuk barang, dilakukan oleh PT Riau Andalan Pulp Paper yang memberikan 3.000 buah bibit pohon bambu. Berdasarkan dokumen Berita Acara Serah Terima (BAST), bibit pohon tersebut diberikan kepada Dinas Ketahanan Pangan, Kelautan dan Pertanian Pemprov DKI Jakarta untuk di tanam pada sejumlah hutan kota dan ruang terbuka hijau. Kegiatan dimaksud dilakukan pada 4 Mei 2016.

Dari Matriks Hasil Rekonsiliasi Aset dalam Kertas Kerja Laporan Keuangan TA 2016 yang tercatat pada Badan Pengelola Aset Daerah, diketahui nilai aset TSLDU/CSR yang telah diserahterimakan dan disajikan pada akun Lain-Lain Pendapatan Daerah yang SahLO senilai Rp.14.307.534.2277. Namun hasil pemeriksaan BPK atas Laporan 
Keuangan Pemprov DKI Jakarta TA 2016 menyatakan lain.

Secara administrasi keuangan negara, pelaksanaan TSLDU harus mengikuti ketentuan peraturan-perundang-undangan mengenai hibah daerah dan penerapan Standar Akuntasi Pemerintahan $^{8}$. Ketentuan mengenai hibah dasarnya diatur dalam UU Nomor 17 tahun 2003 tentang Keuangan Negara dan UU Nomor 1 tahun 2004 tentang Perbendaharaan Negara.

Definisi hibah disebutkan pada UU Nomor 33 tahun 2004 tentang Perimbangan Keuangan antara Pemerintah Pusat dan Pemerintah Daerah sebagai penerimaan daerah yang berasal dari pemerintah negara asing, badan/lembaga asing, badan/lembaga dalam negeri atau perseorangan, baik dalam bentuk devisa, rupiah maupun barang dan/ atau jasa, termasuk tenaga ahli dan pelatihan yang tidak perlu dibayar kembali. Pada Pasal 43 dan Pasal 44 UU tersebut, pendapatan hibah dalam anggaran daerah termasuk bagian dari lainlain pendapatan dan bersifat tidak mengikat.

Mekanisme pengelolaan hibah Pemerintah Daerah diatur pula dalam PP Nomor 58 tahun 2005 tentang Pengelolaan Keuangan Daerah. Ketentuan Pasal 24 jo Pasal 25 menyebutkan bahwa pendapatan hibah dapat berupa uang dan/atau jasa yang berasal dari pemerintah, masyarakat, dan badan usaha dalam negeri atau luar negeri yang tidak mengikat. Berdasarkan Pasal 27 alokasi dana hibah digunakan untuk menganggarkan pemberian uang/barang atau jasa kepada pemerintah atau pemerintah daerah lainnya, perusahaan daerah, masyarakat dan organisasi kemasyarakatan, yang secara spesifik telah ditetapkan peruntukannya, bersifat tidak wajib dan tidak mengingat serta tidak secara terus menerus. Pengelolaan penerima hibah diatur pula dalam Peraturan Pemerintah (PP) No. 10 tahun 2011 tentang Tata Cara Pengadaan Pinjaman Luar Negeri dan Penerimaan Hibah. Dalam Pasal 2 PP No. 10 tahun 2011, prinsip penerimaan hibah terdiri dari transparan, akuntabel, efisien dan efektif, kehati-hatian, tidak disertai ikatan politik dan tidak memiliki muatan yang dapat mengganggu stabilitas keamanan negara. Berdasarkan klasifikasinya, hibah dibedakan atas jenisnya, berupa hibah yang direncanakan dan/ atau hibah langsung, dan berdasarkan sumbernya, yaitu dana hibah dalam negeri maupun luar negeri.

Pengelolaan hibah oleh pemerintah daerah selanjutnya diatur khusus dalam PP Nomor 2 tahun 2012 tentang Hibah Daerah. Dimana hibah daerah merupakan pemberian dengan pengalihan hak atas sesuatu dari pemerintah atau pihak lain kepada pemerintah daerah atau sebaliknya yang secara spesifik telah ditetapkan peruntukannya dan dilakukan melalui perjanjian. Berdasarkan sumbernya, hibah kepada pemerintah daerah dapat berasal dari pemerintah, badan, lembaga, atau organisasi dalam negeri; dan/atau kelompok masyarakat atau perorangan dalam negeri. Berdasarkan 
Pasal 28 ayat (1) dan (2), Pemerintah Daerah melaksanakan penatausahaan atas realisasi hibah dalam bentuk uang, barang dan/atau jasa. Realisasi hibah tersebut kemudian dicatat dalam laporan keuangan pemerintah daerah.

Penatausahaan yang dilakukan oleh pemerintah daerah harus mengikuti ketentuan tentang Penerapan Standar Akuntansi Pemerintahan yang diatur dalam PP Nomor 71 tahun 2010 tentang Standar Akuntansi Pemerintahan. Penerapannya pada pemerintah daerah diatur dalam Permendagri Nomor 64 tahun 2014 tentang Penerapan Standar Akuntansi Pemerintah Berbasis Akrual pada Pemerintah Daerah.

Di dalam Pasal 1 ayat (4) Permendagri Nomor 64 tahun 2014 dinyatakan bahwa SAP Berbasis Akrual adalah SAP yang mengakui pendapatan, beban, aset, utang, dan ekuitas dalam pelaporan finansial berbasis akrual, serta mengakui pendapatan, belanja dan pembiayaan dalam pelaporan pelaksanaan angaran berdasarkan basis yang ditetapkan dalam APBD". Sesuai dengan Buletin Teknis SAP Nomor 12 tentang Akuntansi Hibah $^{9}$, mekanisme pengelolaan hibah ${ }^{10}$ terdiri dari: pertama pendapatan hibah menurut mekanisme penganggaran, meliputi ${ }^{11}$ : (a) hibah yang direncanakan, hibah yang dilaksanakan melalui mekanisme perencanaan dan penganggaran dan diterima oleh entitas yang mempunya fungsi perbendaharaan umum (BUN atau BUD); dan (b) hibah langsung, dalam hal ini adalah hibah yang diterima langsung oleh KL/SKPD tanpa melalui entitas yang mempunyai fungsi perbendaharaan (BUN/BUD) ${ }^{12}$.

Kedua pendapatan hibah menurut bentuknya ${ }^{13}$, terdiri dalam bentuk barang dan jasa, termasuk asistensi, tenaga ahli, beasiswa dan pelatihan. Ketiga pendapatan hibah menurut sumbernya ${ }^{14}$, meliputi institusi/lembaga di dalam negeri termasuk masyarakat dan kelompok masyarakat.

Keempat mekanisme pengelolaan hibah pemerintah daerah yang terdiri dari: (i) hibah yang direncanakan, harus melalui proses perencanaan dan penganggaran serta tertuang di dalam APBD sebagai salah satu sumber pendanaan belanja pemerintah daerah. Hibah yang direncanakan karena telah melalui proses perencanaan dan penganggaran maka secara sistem seharusnya diterima oleh BUD untuk kemudian tertuang dalam dokumen pelaksanaan anggaran (DPA) sebagai

$9 \quad$ Berdasarkan Pasal 2 jo Pasal 3 PP No. 71 tahun 2010, Standar Akuntansi Pemerintahan dinyatakan dalam bentuk Pernyataan Standar Akuntansi Pemerintahan (PSAP) yang dapat dilengkapi dengan Interpretasi Pernyataan Standar Akuntansi Pemerintahan (IPSAP) dan/atau Buletin Teknis SAP. IPSAP dan Buletin Teknis SAP disusun dan diterbitkan oleh Komite Standar Akuntansi Pemerintahan (KSAP) dan diberitahukan kepada Pemerintah dan Badan Pemeriksa Keuangan.

10 Komite Standar Akuntansi Pemerintahan, 'Buletin Teknis Standar Akuntansi Pemerintahan Nomor 13'.

11 Angka 1, poin 3.3 jenis dan klasifikasi Pendapatan Hibah, Bab III Pendapatan Hibah.

12 Hibah ini tidak masuk dalam perencanaan karena hibah diterima tanpa ada naskah perjanjian sebelumnya. Namun demikian, hibah langsung yang diterima dalam periode tahun berjalan dan dapat dimasukkan dalam dokumen perubahan anggaran pada saat penyusunan perubahan anggaran, maka hibah langsung tersebut beralih menjadi hibah yang direncanakan.

13 Angka 2, poin 3.3 jenis dan klasifikasi Pendapatan Hibah, Bab III Pendapatan Hibah.

14 Angka 3, huruf a poin 3, jenis dan klasifikasi Pendapatan Hibah, Bab III Pendapatan Hibah. 
sumber dana pada pembelanjaan SKPD. Pendapatan hibah ini di catat oleh BUD. Sedangkan untuk (ii) hibah langsung, mekanismenya tidak melalui proses perencanaan dan penganggaran serta tertuang di dalam APBD sebagai salah satu sumber pendanaan belanja pemerintah daerah. Jenis hibah ini pada umumnya tidak diterima melalui BUD, melainkan diterima langsung oleh SKPD. Dalam hal memastikan agar hibah berikut belanja yang sumber dananya berasal dari hibah langsung dapat tercatat, maka dilakukan proses pengesahan pengakuan pendapatan hibah serta belanja yang bersumber dari hibah dimaksud yang diajukan oleh SKPD penerima kepada BUD.

Dalam hal pengakuan pendapatan hibah berbasis akrual terkait hak pemerintah, berlaku prinsip bahwa pendapatan hibah berbasis akrual diakui pada saat hak pemerintah timbul ${ }^{15}$. Dimana hak untuk memperoleh pendapatan tersebut dapat timbul walaupun kas belum diterima di rekening kas umum/daerah atau oleh entitas pelaporan $^{16}$. Karena itu terdapat 3 (tiga) kondisi yang menyebabkan pendapatan hibah berbasis akrual sudah dapat diakui, yaitu (a) pendapatan tersebut dapat diidentifikasi secara spesifik; (b) besar kemungkinan sumber daya ter- sebut dapat ditagih; dan (c) jumlahnya dapat diestimasi secara andal. Dari kondisi tersebut, dapat diakuinya Pendapatan Hibah-LO bila persyaratan yang ditetapkan dalam perjanjian hibah telah terpenuhi, yaitu (1) pada saat entitas penerima hibah telah melaksanakan kegiatan atau memenuhi persyaratan tersebut ${ }^{17}$; (2) setelah timbulnya hak yang ditandai dengan perjanjian hibah di tandatangani ${ }^{18}$; dan (3) pada saat dana hibah/barang telah diterima ${ }^{19}$.

Seluruh pendapatan hibah dalam sistem akuntansi berbasis akrual disajikan dalam Laporan Operasional dan Laporan Realisasi Anggaran dengan menggunakan basis kas $^{20}$. Sedangkan pencatatan barang/jasa yang diperoleh pemda sebagai pendapatan hibah dicatat sebesar nilai barang/jasa yang diserahkan berdasarkan Berita Acara Serah Terima. Sesuai dengan PP No. 71 tahun 2010, Lampiran I PSAP 07 menyebutkan dalam paragraph 48 bahwa apabila perolehan asset tetap memenuhi kriteria perolehan asset donasi, maka perolehan tersebut diakui sebagai pendapatan operasional. Sedangkan asset tetap yang diperoleh dari sumbangan (donasi) harus dicatat sebesar nilai wajar pada saat diperoleh.

Pemprov DKI Jakarta dalam mengelola TSLDU, dinilai BPK belum memadai.

\footnotetext{
Poin 3.5 Akuntansi Pendapatan Hibah Angka 2.

PP No. 71 tahun 2010, Lampiran I, KK Paragraf 42.

1 Kondisi ini terjadi apabila pemberi hibah akan mengeluarkan dana atau memberikan barang jika entitas penerima hibah sudah melaksanakan suatu kegiatan atau persyaratan tertentu.

18 Kondisi ini terjadi apabila pemberi hibah akan mengeluarkan dana atau memberikan barang tanpa persyaratan tertentu, sesuai dengan perjanjian antara pemberi dan penerima hibah

19 Kondisi ini terjadi apabila pemberi hibah mengeluarkan dana atau memberikan barang tanpa persyaratan tertentu.

20 Dalam konteks ini Laporan Realisasi Anggaran berposisi pula sebagai statutary report.
} 
BPK melihat dari pola implementasi penerimaan pendapatan TSLDU yang terjadi.

Pada pola pertama Pemprov tidak melibatkan DPRD. Proses penerimaan pendapatan merupakan bagian perencanaan keuangan tahunan Pemda yang seharusnya dibahas dan disetujui bersama Pemerintah Daerah dan DPRD melalui APBD. Ditemukan pula bahwa penerimaan pendapatan TSLDU tidak didahului dengan adanya proses penetapan target penerimaan sebagaimana lazimnya dalam mekanisme APBD. Karena itu proses pengelolaan TSLDU ini tidak mengikuti prosedur yang seharusnya dilakukan.

Pada pola yang kedua, terjadi ketidaktaatan terhadap proses administrasi. TSLDU yang telah diterima Pemprov dan telah dituangkan dalam BAST, ternyata tidak di dahului dengan pembuatan PKS antar para pihak. Akibatnya, TSLDU yang diterima Pemprov DKI Jakarta belum seluruhnya disajikan dalam Pendapatan-LO. Ketidaktaatan proses administrasi ini membuat proses menjadi kurang transparan dan akuntabel. Penerimaan pendapatan TSLDU dari masyarakat/swasta belum seluruhnya disajikan pada Laporan keuangan Pemprov DKI Jakarta.

Selain catatan BPK terhadap pengelolaan TSLDU, FGD pemangku kepentingan TSLDU ${ }^{21}$ mencermati pula tata kelola TSLDU. Terdapat 5 (lima) perma- salahan yang terjadi dalam tata kelola TSLDU yaitu (1) dasar hukum TSLDU belum komprehensif mengoptimalkan potensi yang ada dan membangun sistem pengelolaan terpadu yang transparan dan akuntabel; (2) belum tersedianya data yang valid, lengkap, mudah diakses dan terintegrasi; (3) belum optimalnya dukungan dari dunia usaha dan masyarakat; (4) masih terbatasnya varian kegiatan; dan (5) belum terintegrasinya perencanaan pelaksanaan TSLDU dengan sistem perencanaan pembangunan daerah.

\section{Kerangka Perubahan Tata Kelola Penyenggaraan TSLDU di Kota Jakarta}

Dari hasil FGD, catatan pemeriksaan BPK serta tinjauan literatur dan praktik terbaik pelaksanaan CSR, terdapat 4 (empat) fokus perubahan tata kelola penyelenggaraan TSLDU. Keempat aspek ini menjadi materi perubahan Pergub 112.

1. Penyediaan Informasi dan Tata Kelola Administrasi TSLDU/CSR menggunakan Sistem Informasi berbasis web;

Dalam memfasilitasi kebutuhan serta keterbukaan data dan informasi dalam penyelenggaraan TSLDU, diperlukan dukungan teknologi informasi. Penggunaan teknologi informasi terbukti telah menciptakan transformasi dan value creation dalam tata kelola pelayanan kepada

$\overline{21}$ Pelaksanaan FGD dilaksanakan pada September 2017 dengan difasilitasi oleh Biro Kesejahteraan Sosial Setda Pemprov DKI Jakarta mengundang para pemangku kepentingan yang terlibat dalam pelaksanaan TSLDU/CSR, unsur SKPD/UKPD teknis dan wilayah, pelaku usaha dan BUMD, NGO dan kelompok masyarakat. 
masyarakat ${ }^{22}$. Memanfaatkan jaringan internet, pemerintah daerah dengan mudah dan murah dapat memberikan akses informasi serta menjalin komunikasi yang cepat dan interaktif kepada publik ${ }^{23}$. Selain itu dapat mendorong efektivitas, efisiensi dan transparan dalam penyelenggaraan pemerintahan ${ }^{24}$. Selain itu juga dapat memperkuat partisipasi publik yang lebih luas dalam proses pengambilan keputusan dan pengawasan jalannya pemerintah$\mathrm{an}^{25}$.

Keterbukaan dan kemudahan akses data dan informasi menjadi faktor penting bagi pemangku kepentingan dalam penyelenggaraan TSLDU. Bagi dunia usaha, TSLDU bukan kegiatan amal semata yang tidak membutuhkan perencanaan yang matang. TSLDU merupakan bagian dari tata kelola perusahaan dalam memberikan kontribusi yang bermanfaa bagi seluruh pemangku kepentingan (stakeholder), tanpa terkecuali untuk lingkungan hidup ${ }^{26}$. Perusahaan memiliki tanggung jawab membuat keseimbangan bagi seluruh pemangku kepentingan.

Dalam FGD pemangku kepentingan, terungkap perusahaan kesulitan memperoleh data dan informasi dalam proses perencanaan TSLDU. Sebagian besar kegiatan TSLDU pada tahun 2016, diinisiasi Pemprov DKI Jakarta. Peran aktif Gubernur membangun komunikasi mempengaruhi keputusan perusahaan dalam melaksanakan TSLDU.

Dalam usulan perubahan Pergub 112 , pengembangan sistem pengelolaan TSLDU diarahkan dari bersifat manual ke arah digital. Sistem digital ini berupa Sistem Pengelolaan TSLDU berbasis web (SIMPEL-CSR). Di dalam sistem tersebut terdapat portal SIMPEL CSR sebagai tampilan muka dan dukungan sistem data base pengelolaan TSLDU yang dapat diakses oleh SKPD/UKPD serta terkoneksi dengan sistem perencanaan pembangunan (e-planning) dan sistem pengelolaan hibah (e-hibah) yang dimiliki sebelumnya oleh Pemprov.

Melalui portal SIMPEL-CSR, data dan informasi dapat tersedia bagi semua pihak yang terlibat. Baik data peraturan perundang-undangan pelaksanaan TSLDU; dokumen rencana pembangunan daerah; dokumen tata ruang wilayah, rencana detail tata ruang beserta peraturan zonasi; dan informasi proses perencanaan pembangunan yang

22 Luis F. Luna-Reyes dan J Ramon Gil-Garcia, 'Digital Government Transformation and Internet Portals: The Co-Evolution of Technology, Organizations, and Institutions' (2014) 31 Government Information Quarterly 545, 546.

23 Juan L. Gandía, Lucía Marrahí dan David Huguet, 'Digital Transparency and Web 2.0 in Spanish City Councils' (2016) 33 Government Information Quarterly 28, 30.

24 Ibid.

25 Aikaterini Yannoukakou dan Iliana Araka, 'Access to Government Information: Right to Information and Open Government Data Synergy' (2014) 147 Procedia - Social and Behavioral Sciences 332, 333.

26 Suparman, 'Coorporate Social Responsibility: Bentuk Tanggung Jawab Sosial dan Kepedulian Perusahaan Dengan Masyarakat.' (2013) II Jurnal Interaksi 69, 71. 
tengah berjalan sesuai tahapan. Termasuk pula data dan informasi di level SKPD/UKPD mengenai (a) kegiatan prioritas SKPD; (b) lokasi sasaran kegiatan; (c) jumlah; (d) penanggungjawab, serta (e) data pelaksanaan TSLDU sebelumnya yang telah berjalan di daerah.

Akses data diberikan pula kepada mitra pelaksana dan pemanfaat TSLDU. Para mitra pelaksana dapat menyampaikan proposal untuk terlibat dalam kegiatan TSLDU melalui portal SIMPEL CSR. Proposal tersebut menjadi bahan bagi perusahaan dalam merencanakan kegiatan TSLDU. Begitu pula dengan pihak pemanfaat TSLDU dapat menyampaikan proposal kebutuhan dan/atau usulan kegiatan melalui portal SIMPEL-CSR.

Dengan model ini, SIMPEL CSR berfungsi sebagai clearing house. ${ }^{27}$ Para pihak yang terlibat dengan mudah mengakses data dan informasi yang dibutuhkan sekaligus berfungsi sebagai media pertukaran informasi antar para pihak dalam penyelenggaraan TSLDU. SIMPLECSR menjadi penghubung dan pendukung kerja SKPD/UKPD dan Forum CSR dalam membahas bentuk kolaborasi pelaksanaan TSLDU. Melalui SIMPEL-CSR, proses pelaporan dan verifikasi dijalankan secara elektronik sehingga bisa memudahkan pihak terkait dalam mengevaluasi pelaksanaan TSLDU/ CSR.

2. Mengintegrasikan Dukungan TSLDU dengan Sistem Perencanaan Pembangunan dan Anggaran Daerah

Pelaksanaan TSLDU harus terintegrasi dalam proses perencanaan keuangan tahunan Pemprov DKI Jakarta. Revisi Pergub 112 harus secara tegas dan jelas mengatur pengintegrasian proses ini. Hal ini dilakukan dengan pengintegrasian sistem informasi serta penguatan tugas SKPD/UKPD dalam pengelolaan administrasi TSLDU.

Revisi Pergub 112 harus memperjelas aliran proses beserta pelibatan tugas SKPD/UKPD dalam pengelolaan TSLDU. Semua itu diikuiti dengan pengintegrasian sistem informasi yang ada sebagai satu kesatuan sistem.

3. Perluasan Ruang Lingkup TSLDU/ CSR;

Dalam memanfaatkan potensi dukungan dunia usaha ruang lingkup pelaksanaan TSLDU perlu untuk diperluas. Bidang yang bisa ditambahkan mencakup 3 (tiga) bidang yaitu bina sosial dan keagamaan; bidang pendidikan, olahraga, seni dan budaya; serta bidang kesehatan, untuk melengkapi bidang sebelumnya yaitu bina sosial dan budaya; bina ekonomi; bina fisik 
lingkungan dan penanggulangan bencana.

Perluasan diperlukan pula pada lingkup kegiatan TSLDU. Bentuk kegiatan diperluas mencakup pemberian bantuan pendanaan, penyediaan fasilitas, sarana prasarana serta penyediaan barang dan/atau jasa dan fasilitasi peningkatan sumber daya manusia.

4. Pengembangan Skema TSLDU/CSR Kolaboratif;

Perubahan Pergub 112 diupayakan dapat memperkuat model kolaboratif pelaksanaan TSLDU. Perusahaan diberi ruang untuk berkolaborasi dengan perusahaan lain atau dengan mitra pelaksana agar implementasi TSLDU bisa lebih efisien ${ }^{28}$.

Pemangku kepentingan penyelenggaraan TSLDU, tidak hanya perusahaan selaku inisiator pelaksana, namun dapat melibatkan mitra pelaksana, fasilitator pelaksana dan pemanfaat TSLDU. Mitra pelaksana TSLDU, sebagai pihak yang ingin bermitra dan berkolaborasi dengan inisiator pelaksana TSLDU, dapat merupakan asosiasi/ kelompok profesi, perguruan tinggi, maupun organisasi sosial kemasyarakatan. Fasilitator pelaksana adalah Pemerintah Daerah, sedangkan pemanfaat TSLDU merupakan masyarakat yang dibantu dan/atau tinggal di lokasi sekitar pelaksanaan TSLDU.
Melalui pengembangan skema TSLDU kolaboratif diharapkan tercipta pengembangan kerjasama dan kemitraan antar pemangku kepentingan di daerah. Melalui kerjasama dan kemitraan ini diharapkan mendorong pelaksanaan TSLDU terpadu yang lebih partisipatif dan kolaboratif dengan memperhatikan secara seimbang kepentingan perusahan, pemerintah daerah, masyarakat dan kelestarian lingkungan.

\section{PENUTUP}

Dalam meningkatkan kesejahteraan dan kemakmuran rakyat serta menjaga kelestarian fungsi lingkungan hidup di Provinsi DKI Jakarta dibutuhkan penguatan kemitraan dan kolaborasi peran antara dunia usaha, masyarakat dan pemerintah daerah. Penguatan ini dilakukan dengan mensinergikan pelaksanaan tanggung jawab sosial dan lingkungan dunia usaha, dengan kebijakan, program dan kegiatan pemerintah daerah, serta kebutuhan dan dukungan dari masyarakat. Untuk itu dibutuhkan dukungan pengelolaan yang memfasilitasi pertukaran data dan informasi serta kerjasama dan kolaborasi programkegiatan dari masing-masing pihak.

Saat ini pelaksanaan TSLDU di Provinsi DKI Jakarta telah berjalan berdasarkan Pergub 112. Selama tahun 2016, terdapat 3 jenis kegiatan TSLDU, meliputi (1) TSLDU dalam bentuk aset, (2) TSLDU dalam bentuk jasa, dan (3) TSLDU dalam bentuk barang. Namun 
implementasi tata kelola TSLDU, belum berjalan sesuai ketentuan. Terdapat 5 (lima) permasalahan dalam tata kelola TSLDU. Peraturan yang mengatur TSLDU belum komprehensif mengoptimalkan potensi yang ada dan membangun sistem pengelolaan terpadu yang transparan dan akuntabel. Belum tersedianya data yang komprehensif, mudah diakses dan terintegrasi, dalam memenuhi kebutuhan pelaku usaha, pemerintah daerah maupun masyarakat. Dukungan dari dunia usaha dalam pelaksanaan TSLDU masih belum optimal. Varian kegiatan dalam TSLDU masih terbatas, dan pelaksanaan TSLDU yang belum terintegrasi dengan sistem perencanaan pembangunan daerah.

Dalam mendorong perbaikan tata kelola penyelenggaraan TSLDU, terdapat 4 (empat) aspek yang harus dibenahi. Keempat aspek ini sekaligus merupakan usulan perubahan Pergub No. 112 yang meliputi (1) penyediaan informasi dan tata kelola administrasi TSLDU menggunakan sistem informasi berbasis web; (2) mengintegrasikan dukungan TSLDU dengan sistem perencanaan pembangunan dan anggaran daerah; (3) Perluasan ruang lingkup TSLDU; dan (4) Mengembangkan skema TSLDU kolaboratif.

\section{DAFTAR BACAAN}

\section{Buku dan Jurnal}

Gandía, Juan L., Marrahi., Lucia \& Huguet, David. 'Digital Transparency and Web 2.0 in Spanish City
Councils' (2016) 33 Government Information Quarterly 28.

Jalal, 'CSR Untuk Pembangunan Perkotaan Yang Berkelanjutan' (FGD Penyusunan Buku The State of Indonesian Cities 2017, Jakarta, Agustus 2017).

Luna-Reyes, Luis F., \& Gil-Garcia, J Ramon, 'Digital Government Transformation and Internet Portals: The Co-Evolution of Technology, Organizations, and Institutions' (2014) 31 Government Information Quarterly 545.

Pahl-Wostl, Claudia, 'Participative and Stakeholder-Based Policy Design, Evaluation and Modeling Processes' (2002) 3 Integrated Assessment 3.

Seidman, Ann \& Seidman, Robert B, 'Instrumentalism 2.0: Legislative Drafting for Democratic Social Change' (2015) 5 Legisprudence 95.

Seidman, Ann \& Seidman, Robert B, 'ILTAM: Drafting Evidence-Based Legislation for Democratic Social Change' (2009) 89 Boston University Law Review 435.

Soekanto S and Mamudji S, Penelitian Hukum Normatif: Suatu Tinjauan Singkat (PT Raja Grafindo Persada 1993) 1.

Suparman, 'Coorporate Social Responsibility: Bentuk Tanggung Jawab Sosial dan Kepedulian Perusahaan Dengan Masyarakat.' (2013), II, Jurnal Interaksi 69. 
Wibowo, Gatot Dwi Hendro, 'Analisis

Kebijakan Pengelolaan Hasil Hutan

Bukan Kayu (HHBK) Di NTB Dan

NTT' (2014) 44 Jurnal Hukum \&

Pembangunan 197.

Yannoukakou, Aikaterini \& Araka Iliana,

'Access to Government Information:

Right to Information and Open

Government Data Synergy' (2014)

147 Procedia - Social and Behavioral

Sciences 332.

\section{Perundang-undangan dan dokumen}

lain

BPK Perwakilan Provinsi DKI Jakarta,

'Laporan Hasil Pemeriksaan Atas

Laporan Keuangan Pemerintah

Provinsi DKI Jakarta Tahun Anggaran

2016' (BPK Perwakilan Provinsi DKI Jakarta).

Komite Standar Akuntansi Pemerintahan, 'Buletin Teknis Standar Akuntansi Pemerintahan Nomor 13.'

Peraturan Gubernur Provinsi DKI Jakarta Nomor 112 Tahun 2013 Tentang Tanggung Jawab Sosial dan Lingkungan Dunia Usaha [Berita Daerah Provinsi DKI Jakarta Tahun 2013 Nomor 75018]. 
